\title{
Niemiejskie funkcje w strukturach zurbanizowanych jako katalizator życia w mieście
}

\author{
Justyna Kleszcz
}

\begin{abstract}
Katedra Architektury i Urbanistyki, Wydziat Budownictwa, Architektury i Inżynierii Środowiska, Uniwersytet Zielonogórski,e-mail: j.kleszcz@aiu.uz.zgora.pl
\end{abstract}

Streszczenie: Niniejszy tekst ma za zadanie przybliżyć rolę wielofunkcyjnych struktur łączących funkcje typowo miejskie z niemiejskimi w jedną formę przestrzenną, dzięki którym stają się one punktami węzłowymi w skali lokalnej oraz ponadlokalnej. Do punktów tych należeć będą obiekty architektoniczne w różnej skali - zarówno te budujące przestrzeń poprzez kubaturę, jak i tworzące jedynie ramy przestrzenne - „antykubaturę”. Wprowadzenie do miast funkcji zwyczajowo kojarzonych $\mathrm{z}$ terenami wiejskimi, jak np. agrokultura w różnej postaci, hodowla zwierząt, przetwórstwo czy przemysłowa produkcja rolna staje się inspiracją do tworzenia nieoczywistych połączeń z funkcją mieszkaniową, komunikacyjną, biurową, edukacyjną, nie tylko zaś z obszarem zieleni rekreacyjnej w mieście. Coraz częściej też budynki tego typu stają się elementami ikonicznymi, zarówno w warstwie realnej, jak i w wirtualnej przestrzeni miasta „niezrealizowanego”. Przykłady utopijnych wizji tworzonych dla największych metropolii, jak Nowy Jork, Paryż, czy Vancouver ukazują znaczenie niewielkiej korekty programu funkcjonalnego danej przestrzeni, pozwalającej przekształcić ją z pobocznej w węzłową. Pasona Urban Farm w Tokio, wizje Vincenta Callebaut, pracowni WORK Architecture Company czy grupy Terreform, lecz również bardziej kameralne realizacje Amersfoort oraz Villa Augustus w holenderskim Dordrecht, Hoeve Biesland ukazują potęgę drzemiącą w niemiejskich funkcjach centrotwórczych.

Slowa kluczowe: miasto, agrokultura miejska, farma miejska, Agropolis, agrihood.

\section{Wstęp}

Niniejszy artykuł ma na celu przybliżenie zagadnienia lokalizowania w przestrzeniach zurbanizowanych funkcji, które dotychczas uważane były za tradycyjnie nie związane z przestrzeniami miast. Są to funkcje nawiązujące $w$ większości przypadków do ich fizycznej / biologicznej sfery (jedzenie, dzika przyroda, natura) w odróżnieniu od ich sfery duchowej, tradycyjnie z miastem związanych (kultura, polityka, handel). Próba określenia, jakie przyczyny powodowały wytworzeniem tego podziału, wywołującego od zawsze silne antagonizmy pomiędzy bezpieczną przestrzenią a tym, co nieznane, znajdujące się dotychczas poza jego granicami prowadzi do zdefiniowania pojęcia nie-miejskości. Do tego typu niemiejskich funkcji w obecnej sytuacji będą należały: rolnictwo w szerokim spektrum przyjmowanych form przestrzennych, miejska przemysłowa produkcja rolna, zwłaszcza ,produkcja” mięsa, lecz również obecność dzikich i nie-dzikich zwierząt. O roli tych elementów, nowo pojawiających się w przestrzeniach zurbanizowanych decyduje ich znaczenie jako punktów węzłowych, katalizujących procesy społeczne zachodzące wewnątrz dotychczas zwartej struktury urbanistycznej. W procesie tym wyróżnimy dwa rodzaje form przestrzennych, mogących tworzyć tego typu węzły - obiekty kubaturowe oraz anty-kubaturę, czyli niezabudowane 
przestrzenie w mieście. Tworzą one różne układy przestrzenne, głównie punktowe, rzadziej liniowe lub płaszczyznowe, stanowiące silny atraktor społeczny lub obiekt ikoniczny o nietypowej funkcji i formie, jako nowe punkty ciążenia w strukturach zurbanizowanych.

\section{Funkcje miejskie i niemiejskie - przyczyny podziału}

Podział na tradycyjne miasta funkcjonalne oraz tereny ruralne wyniknął $\mathrm{z}$ historycznych uwarunkowań związanych z koniecznością grupowania funkcji związanych z produkcją rolną oraz zabezpieczeniem zaplecza gospodarczego, handlowego, a w dalszej perspektywie również politycznego, administracyjnego i kulturowego. Strefy funkcjonalne miasta kupieckiego, a od XIX wieku - również przemysłowego spowodowały powstanie rodzaju przemysłowego antymiasta, powodującego silną polaryzację głównych funkcji: mieszkania, handlu, administracji, kultury i przemysłu [1], [2]. O ile jednak duży racjonalizacja podejścia do projektowania strefowego miasta wynikała w przeszłości ze znacznej uciążliwości dla mieszkańców, dużego zanieczyszczenia środowiska oraz pewnych szczególnych wymagań infrastrukturalnych osiąganych jedynie punktowo (jak np. dostępność kolei, przywóz surowców naturalnych itp.) przy ograniczonej powierzchni terenów zurbanizowanych było uzasadnione, o tyle pozostawanie na etapie strefowania dużych obszarów, aglomeracji i metropolii oraz próba ochrony hermetyczności miejskich funkcji wydaje się w obecnych czasach znaczącym anachronizmem. Krier, analizując podział funkcjonalny miast ery przemysłowej zauważył rolę strefowania w pojawieniu się i rozwoju segregacji społecznej wynikającej z wewnętrznej migracji ludzi pomiędzy poszczególnymi strefami, co powodowało jednocześnie hierarchizację jego wewnętrznej struktury. W takiej sytuacji funkcje lokalizowane na terenach miejskich, jako centrum aktywności społeczno-gospodarczych danego regionu zajmowały niższą pozycję niż te w obrębie obszarów zurbanizowanych.

Podział funkcji na miejskie i niemiejskie można analizować uwzględniając nie tylko zjawisko deprecjonowania ich znaczenia jako elementów wyższej rangi, lecz również w płaszczyźnie filozoficznej zmiany podejścia do podmiotowości człowieka i jego roli w kreowaniu przestrzeni zamieszkania. Miasto, jako przejaw wyższości człowieka nad przyrodą, w tym ujęciu stało się jednocześnie miejscem obrony przed tym, co nieznane. Stało się wyrazem dążenia człowieka do wyparcia swej biologicznej natury poprzez oddzielenie symboliczną granicą strefy zurbanizowanej od elementów życia związanych z koniecznością walki o byt, rozumianą chociażby jako produkcja żywności i związane z tym konieczność zadawania cierpienia innym organizmom żywym.

Skrajnym przejawem tego typu poglądów jest próba zdefiniowania genezy miast w ujęciu zoogeografii. Zgodnie z poglądami Philo [3] na temat znaczącej roli zwierząt w historycznym wydzieleniu obszarów zurbanizowanych z terenów wiejskich, miał fakt dążenia człowieka do ograniczenia ciężaru psychicznego, jaki na mieszkańcach danego obszaru wywierała bliskość rzeźni, targów bydła itd. związana w całości z biologią życia i śmiercią zwierząt. Zagadnienie to wiąże się również z ukształtowaniem kolejnej dziedziny nauki, jaką jest miejska zooekologia, postrzegana w kontekście bardziej wysublimowanej formy miejskiej ekologii oraz polityki rozwoju zrównoważonego, który można wprowadzać w życie już po osiągnięciu pewnych podstawowych założeń $\mathrm{w}$ tym zakresie dotyczących wybranych fizycznych parametrów środowiska zurbanizowanego [4]. Wraz ze zmianą podejścia do pojmowania miejskiego ekosystemu jako siedliska nie tylko człowieka, ale również szeroko rozumianej dzikiej przyrody, pojawiła się szansa na usankcjonowanie faktu wprowadzenia dodatkowych funkcji w przestrzeni miast, związanych z obecnością w niej przedstawicieli świata zwierząt i roślin. 
Kolejne możliwości wprowadzenia niemiejskich funkcji na obszarach zurbanizowanych pojawiły się wraz z wykrystalizowaniem nowych definicji miasta związanych z próbą ponownego określenia przestrzeni zamieszkałych przez człowieka w dobie odchodzenia od tradycyjnej jego funkcji i formy.

Bezpośrednie powiązanie pojęcia miasta stworzonego przez ludzi (polis) i świata zwierząt (zoo) następowało jako długotrwały, wielopłaszczyznowy proces poszerzania znaczenia podmiotowości zwierząt w kulturze światowej, sztuce i polityce. Samo pojęcie zoopolis [5] zostało na początku zastosowane właśnie w odniesieniu do nauk politycznych, w kontekście przestrzeni współużytkowanych przez człowieka i zwierzęta domowe, gdzie miasto rozumiano jako wspólnotę polityczną jej mieszkańców, a wywodzące się z młodszego o 13 lat określenia zoopolia stworzonego w odniesieniu do środowiska zbudowanego przez Jennifer Wolch [6].

Pojawienie się alternatywnych definicji przestrzeni zurbanizowanych opierających się na zmianie tradycyjnie pojmowanej roli miasta w aspekcie geopolitycznym, kulturowym, społecznym, filozoficznym, czy przestrzennym stawia pod znakiem zapytania możliwość określenia prawdziwej „miejskości” przestrzeni, ale też uzmysławia konieczność zmiany tradycyjnego podejścia do przestrzeni historycznie ukształtowanych, jako formy anachronicznej.

\section{Alternatywy miasta}

Zoopolia jest wersją przestrzeni zurbanizowanej stworzoną przez Jennifer Wolch [7] jako alternatywne, ale i dopełniające znaczenia metropolii, jednak przeznaczonej zarówno dla ludzi, jak i zwierząt, a szerzej - natury. W związku z tym, że tereny zajmowane przez dziką przyrodę zanikają nie tylko w obszarze, lecz również poza strefami urbanizacji, utrzymanie tradycyjnej formy miasta spowoduje znaczące zubożenie środowiska życia człowieka oraz natury jako całości. Definicja ta opiera się o nowo sformułowaną zasadę projektową zwaną projektowaniem nieantropocentrycznym. Jest to definicja odnosząca się bezpośrednio do sposobu postrzegania dzikich zwierząt we współczesnych strukturach miejskich, jako elementu wiążącego dla zachowania ścisłej relacji pomiędzy człowiekiem a zwierzęciem w przestrzeniach przekształconych poprzez obecność człowieka. Wspomniana wcześniej zoogeografia daje w tym wypadku naukowe podstawy do analizy działań w przestrzeni miejskiej opartej na zasadach tzw. kulturowej geografii zwierząt, związanej z procesem udomawiania zwierząt i bazującej na geografii humanistycznej i naukach społecznych. Z drugiej jednak strony mamy do czynienia z obecnością nowo rozwijającej się dziedziny wiedzy, przy jednoczesnym braku naukowych podstaw do dyskusji nad rolą dzikich zwierząt w przestrzeni miast, czy wręcz na zjawisko wypierania w pracach urbanistycznych faktu obecności dzikiej przyrody zgodnie z poglądem, że przestrzenie zurbanizowane są wyłączną domeną człowieka.

Współużytkowanie przez ludzi i zwierzęta stało się pierwszą z możliwości rozbudowy funkcjonalnej poprzez poszerzenie grupy użytkowników o ich „niemiejską” - dziką strefę. Dotyczyć to będzie zjawisk takich, jak rewilding [8], czyli w wypadku przestrzeni zurbanizowanych - pozostawiania fragmentów przestrzeni pozostającej w ścisłej relacji ze strukturami zurbanizowanymi zamieszkałymi przez człowieka - w formie otwartej, przeznaczonej do celowej renaturyzacji, ,zdziczenia krajobrazu” często w ekstremalnych przyrodniczo formach. Będzie ono dotyczyć zarówno obszarów przyjmujących formę płaszczyzn, jak i rozmieszczonych punktowo wewnątrz miast. Obszary takie, jak rezerwat Oostvardensplassen pomiędzy miejscowościami Almere i Lelystad, podawany jako pierwszy i najpełniejszy przykład tego typu działań, czy Richmond Park w Londynie, obszar rzeki Wandle 
w Londynie [9], czy walijskiego Cambrian Wildwood [10] dowodzi możliwości kulturotwórczych, jakie posiadają obszary przeznaczone na siedliska dzikich gatunków w przestrzeniach zurbanizowanych.

Agropolis, jako idea przestrzenna pojawia się w kontekście zderzenia pojęć: łacińskiego ager, oznaczającego pole oraz greckiego polis - miasto. We współczesnej formie zostało rozpowszechnione przez Mougeota [11] i odnoszące się do idei miasta pól oraz miasta agrarnego. Jest to również nazwa jednego z programów mikrograntów International Development Research Centre, opartego na działaniach mających na celu integrację gospodarczą Brazylii, podjętego w latach 70-tych XX wieku i bazującego na przekształceniu odseparowanych agrovilas $\mathrm{w}$ kompleksowe lokalne centra ekonomiczne agropoles. W sytuacji, gdy struktura typowo urbanistyczna ulega podziałowi, gdy ze względu na zjawisko rozlewania się granice przestrzeni przestają być ciągłe, a zaczynają zawierać w sobie nieciągłe, punktowe obszary o odmiennym charakterze, najczęściej rolnym lub leśnym, nie można już mówić o jasnym podziale na miasto i wieś. Stwarza to możliwość wykorzystania owych punktów, do tej pory niezagospodarowanych, na potrzeby funkcji stających się potrzebne w danym miejscu właśnie w związku z rozciągnięciem struktur zabudowy.

Warto zresztą prześledzić zmiany w sposobie definiowania miejskiego rolnictwa jako zjawiska przestrzennego, od form tymczasowych i nietrwałych, po przyjęcie jego roli trwałego, współczesnego elementu ich funkcjonowania, realizującego określone potrzeby społeczne. Obecnie najczęściej przyjmowana definicja określa produkcję rolną w miastach jako „działalność w zakresie wytwarzania, przetwarzania $i$ dystrybucji produktów żywnościowych, nieżywnościowych, chowu zwierząt oraz upraw leśnych na terenie miast oraz obszarów podmiejskich" [12].

\section{Kubatura i anty-kubatura}

O ile łatwo sobie wyobrazić obiekty kubaturowe, architekturę pretendującą do roli ikony, symbolu współczesności miasta wyrażonej poprzez formę architektoniczną jako katalizator życia społecznego, kulturowego itp., o tyle znacznie trudniej spodziewać się podobnego efektu w wypadku przestrzeni pomiędzy architekturą, pustych fragmentów zagospodarowywanych czasowo. Taką właśnie ramę przestrzenną tworzą głównie zakładane obecnie w większych zespołach miejskie farmy, czy inne formy agrourbanistyczne. W tym wypadku zieleń uprawna tworzy scenerię dla zachodzących na wygradzanych terenach zdarzeń społecznych, kulturalnych itp. Paradoksalnie też przyczynia się ona do powrotu do idei historycznego miasta handlowego, bezpośredniego, katalizującego powstawanie placów targowych, hal umożliwiających zakupy od producentów w komfortowych warunkach. W ten sposób przyczyniają się do zacieśnienia relacji pomiędzy wytwórcą a konsumentem żywności, od czego odwrócono się wraz z upowszechnieniem produkcji przemysłowej i wielkoskalowej.

Eemstad Boerderij [13, s.30], blisko 8 - hektarowa farma na terenie miejskich nieużytków w holenderskim Amersfoort oraz systemu redystrybucji w formie sieci sklepików oferujących lokalnie wytworzoną żywność zrzeszonych w sieć Landwinkel [13, s.32] stanowią przykład zrealizowania tej właśnie wizji. Potwierdzają to teoretyczne rozwiązania proponowane między innymi dla osiedli nowojorskich, jak Infoodstructure, wizja rozwiązania problemów społeczno-medycznych wynikających ze znacząco utrudnionego dostępu do świeżej, nieprzetworzonej żywności w rejonie dzielnicy Brooklyn w obszarze Bushwick i Bedford-Stuyvesant [14]. Przekształcenie większego obszaru dzielnicy z uwzględnieniem hierarchicznego rozmieszczenia punktów redystrybucji żywności podzielonych ze względu 
na zasięg stref dojścia pieszego z wyróżnieniem trzech dużych centrów w skali dzielnicy oraz ponad-dzielnicową, a także małe punkty sprzedaży o rozkładzie zapewniającym bezpośredni dostęp do przynajmniej jednego z nich z każdego z kwartałów. Inne rozwiązanie modelowe, na razie pozostające $w$ fazie teoretycznych rozważań, acz przeznaczone do realizacji w holenderskim Almere z 2016 roku, zakłada podobny model równomiernej redystrybucji w niewielkich punkach, skupiających wokół siebie główne funkcje osiedla związane z jego codziennym funkcjonowaniem. Koncepcja samowystarczalnej jednostki osadniczej ReGen Village [15] autorstwa pracowni EFFEKT została zaprezentowana na Biennale Architektury w Wenecji, jako projekt nowej wspólnoty - samowystarczalnej jednostki mieszkaniowej. Zakłada ona odwrócenie tradycyjnej, miejskiej struktury zamieszkania zarówno w sferze przestrzennej, jak i ekonomicznej oraz ekologicznej, zakładając model funkcjonowania, w której to cały zespół, poprzez zastosowanie konkretnych rozwiązań technologicznych i urbanistycznych, ma zapewnić mieszkańcom odnawialną energię, wodę, żywność oraz relatywnie tanie lokum [16]. Samowystarczalność surowcowa, żywnościowa, energetyczna oraz brak oddziaływania na środowisko poprzez produkcję odpadów, ścieków itp. stanowi dopełnienie przekształconego schematu osiedla. Zespół przypomina dawny układ kasztelowy, jednak bez wyraźnie wyznaczonych granic zewnętrznych. Główne kierunki rozwoju urbanistycznego wyznaczone są przez rozwój wewnętrzny, sieciowy oraz centryczny, przy zaproponowanej formie architektonicznej obiektów będących przetworzeniem archetypicznego motywu domu. Zewnętrzną strefę stanowi zabudowa mieszkaniowa przemieszana $\mathrm{z}$ terenami parkingów i infrastruktury technicznej. Drugi pierścień stanowi strefa aktywności społecznych, rekreacji oraz edukacji, połączona bezpośrednio i częściowo przemieszana ze strefą uprawną. W zespole tym nie zostały wydzielone strefy zieleni miejskiej. Stanowią one fragment każdego z typów funkcji, zarówno wewnętrznej, jak i zewnętrznej. Część centralną tworzą otwarte tereny, których ramy przestrzenne tworzone są przez architekturę miejskich farm.

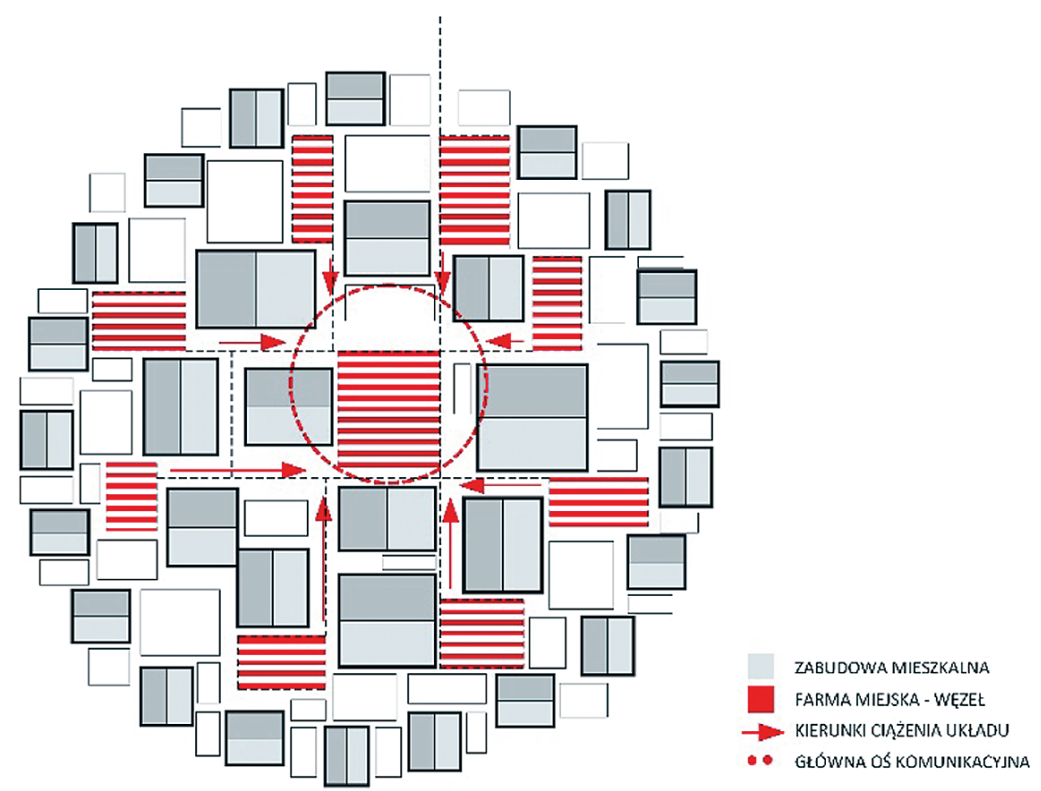

Rys. 1. Schemat kierunków ciążenia układu osiedla ReGen Village z punktami węzłowym w postaci farmy miejskiej 

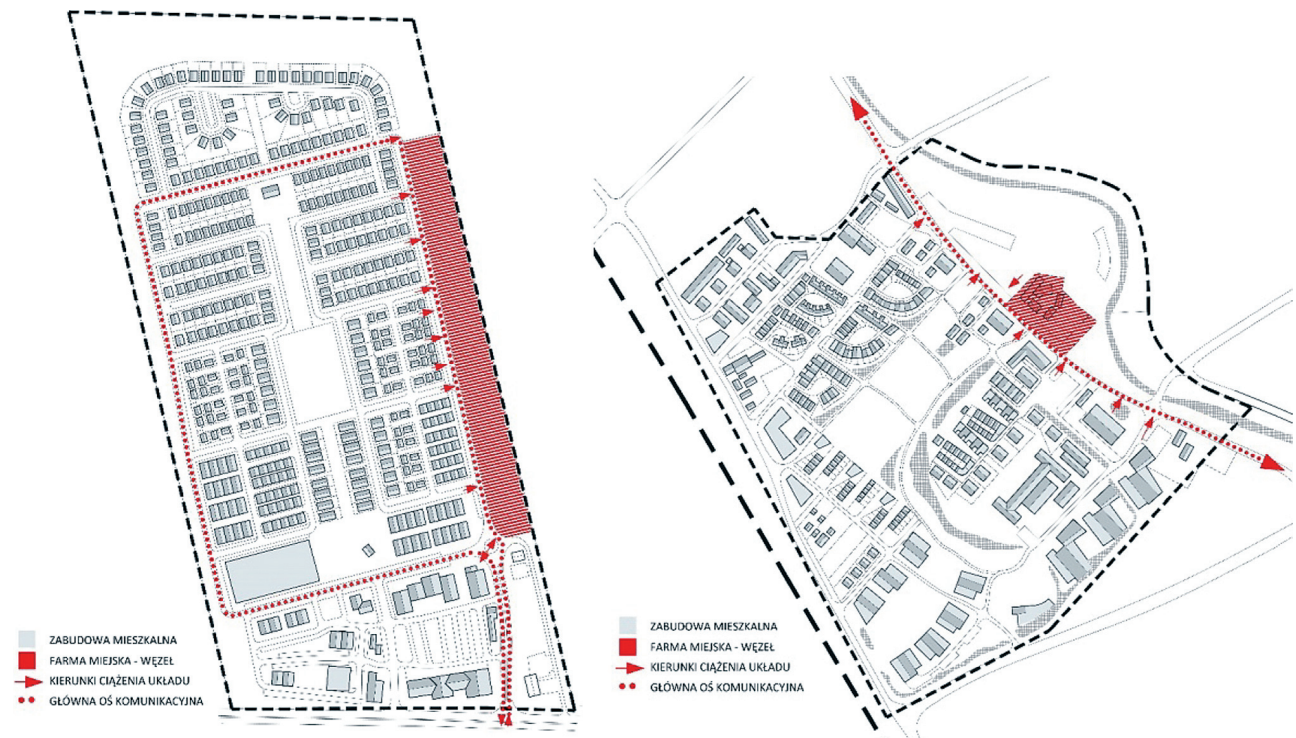

Rys. 2. Schemat kierunków ciążenia układu osiedli Cannery oraz EVA-Lanxmeer z punktami węzłowym w postaci farmy miejskiej

Rozdrobnienie funkcji węzłowej jest charakterystycznym zjawiskiem dla rozwiązań koncepcyjnych, których dwa przykłady zostały opisane powyżej. Dla architektury i urbanistyki zrealizowanej, rozwiązanie to zastępowane jest, w wypadku funkcji związanych z miejskim rolnictwem - silnie scentralizowanymi i spolaryzowanymi punktami węzłowymi, mającymi na celu skupić całość podejmowanych działań. Pozostała przestrzeń osiedla pełni w tym wypadku rolę i przyjmuje formy tradycyjne, w układzie hierarchicznie podporządkowanym centrum.

Farma Caetshage, stanowiąca część osiedla EVA-Lanxmeer w holenderskim Culemborgu powstała jako ostatni element osiedla, na obszarze ochrony ujęcia wody pitnej. Charakterystycznym elementem tego rozwiązania jest przedzielenie produkcyjno-rekreacyjnego centrum, którego jedynym elementem architektonicznym jest zespół niskich zabudowań miejskiej farmy, od pozostałej części osiedla drogą przelotową, wzdłuż której rozmieszczono również po drugiej stronie funkcje biurowe, handlowe i edukacyjne. Zabudowa mieszkaniowa jest odsunięta $\mathrm{w}$ głąb zespołu i przyjmuje formy znane już z innych, wcześniejszych rozwiązań osiedli tworzonych w oparciu o zasady rozwoju zrównoważonego.

W przeciwieństwie do wcześniejszych przykładów, w wypadku amerykańskiego osiedla Cannery w Davis, które również jest nazywane osiedlem typu agrihood, schemat ten nie jest spełniony nawet w tak małym stopniu. Osiedle to charakteryzuje silna polaryzacja funkcji z podziałem na poszczególne strefy. Miejska produkcja rolna, która zlokalizowana została w pasie wzdłuż wschodniej granicy osiedla, pełni rolę głównie rekreacyjną, podobnie jak pas zieleni uzupełniający zewnętrzną otoczkę zespołu mieszkaniowego od strony północnej i zachodniej. Jest to przestrzeń traktowana na równi z terenami sportowymi znajdującymi się w centralnej części osiedla. Brak logicznej relacji pomiędzy teoretyczną produkcją rolną, a strefą handlu i usług widoczny jest w braku fizycznego połączenia tych obszarów. Tereny handlowe i biurowe, oparte głównie na handlu wielkopowierzchniowym oraz pasażach handlowych „typu europejskiego”, tj. dostępnych z otwartych pasaży, nie zaś z zamkniętej 
galerii, opierają się głównie na towarach dostarczanych z zewnątrz i wymagające dojazdu samochodem,. Jest to tradycyjny element modelu funkcjonowania miast amerykańskich [17], których punkty węzłowe w mikroskali sprowadzono do poziomu węzłów komunikacyjnych miejskiej sieci transportowej [18]. Stanowi to w dalszy ciągu realizację wizji suburbanizacji amerykańskiej, znanej od czasów Usonii F.L. Wrighta oraz Regional Pattern L. Hilberseimera. Zespół ten posiada jednak również rozbudowany układ dróg rowerowych oraz pieszych połączonych z obszarami zieleni parkowej i produktywnej, która nie stanowi jednak centralnego punktu osiedla, a jedynie uatrakcyjnienie sposobu zamieszkania.

Jak wykazują przykłady, w części rozwiązań, głównie dotyczących zespołów mieszkaniowych, następuje odejście od ich modelowania poprzez nadanie roli centrotwórczej wielofunkcyjnym obiektom i grupom, a właśnie powrót do skupiania miejskiego życia wokół wolnej przestrzeni - anty-kubatury, której nadaje się znane już historycznie funkcje agory, placu handlowego i miejsca spotkań poza obiektami architektonicznymi. Owa próba przywrócenia różnych form życia społecznego w przestrzeni poza budynkami na również na celu budowę wspólnoty opartej na podtrzymaniu nowo wprowadzanych do miast funkcji rekreacyjnych, produkcyjnych i handlowych.

\section{Linie, płaszczyzny, węzły - obiekty ikoniczne o nietypowej funkcji, nowe punkty ciążenia w strukturach miejskich}

Innym sposobem na stworzenie przestrzeni katalizującej życie społeczne na obszarach zurbanizowanych jest, znane w historii, tworzenie obiektów monumentalnych, czy też, jak nazwalibyśmy to obecnie - ikon architektonicznych mających powtórzyć tzw. „efekt Bilbao”. Jedną nowością $\mathrm{w}$ tym procesie jest jednak próba zakorzenienia w przestrzeni miejskiej nowych funkcji i form właśnie poprzez tworzenie z nich na wstępie nowych symboli urbanizacji. Jest to pewne odwrócenie logiki postępowania z przestrzenią społeczną, gdzie najpierw należy owe zjawisko poznać i oswoić, dopiero potem zaś uznawać je, (bądź nie) za symbol czasów. Próba triumfu nowoczesności nad zastałymi formami i funkcjami miejskimi przejawia się obecnie w tworzeniu spektakularnej pod względem formalnym architektury, stanowiącej jednocześnie eksperyment społeczny nad możliwością tworzenia obiektów samowystarczalnych, a zarazem wielofunkcyjnych. Są one samowystarczalne nie tylko pod względem energetycznym, do czego przyzwyczaiła nas architektura pasywna oraz założenia OZE, lecz również - lub bardziej - a zwłaszcza, żywieniowym, zapewniając jednocześnie miejsce życia, pracy, zamieszkania i rozrywki, utylizując odpady w ramach jednostki oraz wytwarzając w większości przypadków tyle energii, by ograniczyć do zera zapotrzebowanie zewnętrzne. Niewiele z tego typu ikonicznych punktów ma szansę stać się w rzeczywistości węzłami miejskiego życia społecznego. Można podejrzewać, że atrakcyjna forma będzie przyciągać osoby z zewnętrz jako ciekawostka architektoniczna rozpoznawalna poza granicami miasta, stając się formalnym symbolem, jednak bez faktycznego wpływu na życie tej części mieszkańców. Niewiele jest przykładów obiektów stających się jednocześnie atraktorem życia społecznego wewnątrz, i pretendujących do miana symbolu miasta, dzielnicy czy osiedla.

Koncepcyjnymi rozwiązaniami, które próbują stworzyć faktyczną więź pomiędzy projektowanym obiektem, a istniejącą tkanką miejską są np. Plug-Out pracowni WORK ac (2009), Harvest Green Project autorstwa Ramses Architects (2011), Hyperions Vincenta Callebaut (2016). Obiekty te charakteryzują się wielofunkcyjnością, łącząc elementy miejskiego programu funkcjonalnego w jeden wertykalny układ, aby na jak najmniejszej powierzchni rozwiązać jak najwięcej problemów objawiających się w danej przestrzeni. 
Innym typem koncepcji są rozwiązania, których programy funkcjonalne nawiązują do znacznie radykalniejszych poglądów na społeczne kształtowanie miasta lub które starają się rozwiązać pewne problemy w sposób totalny. Wykazują też one większy radykalizm formy, próbując zdefiniować nowy rodzaj estetyki, nawiązujący do form organicznych, jednak bardzo silnie zindustrializowanych. Wśród przykładów znajdują się w tym wypadku rozwiązania przemysłowej, miejskiej hodowli zwierząt na mięso, jako próba odpowiedzi na pytanie o problem dużych areałów niezbędnych do tego typu tradycyjnej ,produkcji” przemysłowej. Wertykalna farma drobiu Self-Reliant New York autorstwa Michaela Sorkina i pracowni Terreform (2014) czy projekt, który zapoczątkował dyskusję o gettoizacji miejskiej hodowli zwierząt i jej wpływie na dobrostan zwierząt hodowlanych - Pig City autorstwa pracowni MVRDV (2001). W tym kontekście projekty takie, jak Self-Sufficient Skyscraper Michaela Sorkina (2010), czy Dragonfly Vincenta Callebaut (2009) stanowią jedynie popis możliwości technicznych i wizjonerstwa jego twórców.

Koncepcje Greenhouse Plantagon, zamkniętej farmy pionowej w szwedzkim Linköping autorstwa Sweco i Plantagon International AB (2012) stanowią odzwierciedlenie, w realnej skali, tych właśnie wizji - chęci stworzenia laboratorium doświadczalnego, w którym w sterylnych warunkach będą testowane relacje przestrzenne i sposób funkcjonowania nowego miasta o odmiennej funkcjonalności oraz które będzie stanowiło symbol nowej urbanistyki - choć w analizie zachodzących w przestrzeni procesów biologicznych bardziej zbliżone do natury, to jednak w swojej warstwie formalnej - znacznie bardziej stechnicyzowane i zdehumanizowane, chcące, wraz ze zbliżeniem miast do natury, tym silniej odgrodzić człowieka od biologicznej sfery życia.

\section{Podsumowanie}

Jak wykazała niniejsza analiza, nie-miejskie funkcje w strukturach zurbanizowanych mogą stanowić silny katalizator życia społecznego, jako element pobudzający tworzenie relacji społecznych opartych na funkcjonowaniu w nowych, przekształconych strukturach urbanistycznych. Zjawisko to przebiega inaczej w miastach europejskich, skupiając się zwłaszcza wokół budowania więzi społecznych i zacieśnianiu relacji człowieka z przyrodą. Forma architektoniczna w tym wypadku jest pochodną rozwoju w Europie nurtu architektury ekologicznej, tworzonej w oparciu o zasady zrównoważonego rozwoju oraz nastawione na jak najmniejszą ingerencję człowieka w środowisko naturalne, również w wypadku budowanych osiedli ludzkich. Model amerykański natomiast jest znacznie bardziej spolaryzowany. Z jednej strony zakłada on tworzenie wyraźnie spektakularnych form architektonicznych, nastawionych na wykorzystanie najnowszych technologii w celu osiągnięcia szeregu korzyści związanych z jakością tworzonej przestrzeni, z drugiej zaś część z proponowanych rozwiązań stanowi kalkę propozycji europejskich pod kątem formalnym, jednak będących w rzeczywistości realizacją doktryny urbanistyki amerykańskiej i sposobu życia propagowanego przez świat kultury Zachodu, wykorzystujący pojawiające się nowe idee i funkcje miejskie jako metodę na uatrakcyjnienie i lepsze skomercjalizowanie przestrzeni zamieszkania.

\section{Literatura}

[1] Krier L. Architektura wspólnoty. Słowo, obraz, terytoria, Gdańsk 2011, 178.

[2] Chmielewski J.M. Teoria urbanistyki w projektowaniu i planowaniu miast. Oficyna Wydawnicza Politechniki Warszawskiej, Warszawa 2005, 35. 
[3] Philo C. Animals. Geography and the city. Environment and planning D 13 (1995) 655-681.

[4] Pulido L. Rethinking environmental racism, Association of American Geographers 90(1) (2000) $12-40$.

[5] Donaldson S., Kymlicka W. Zoopolis. A Political theory of animal rights. Oxford University Press, Oxford, 2011, 156-157.

[6] Wolch J. Anima Urbis, [w:] Architectural theories of the environment: posthuman territory (ed. A. Lourie Harrison), Routledge, Nowy Jork 2013, 233.

[7] Wolch J., Owens M. Animals in contemporary architecture and design, Humanimalia: a Journal of Human/Animal Interface Studies 8 (2017) 1-26.

[8] Monbiot G. Feral. Rewilding the land, the sea, and human life, The University of Chicago Press Books, Chicago 2014.

[9] http://www.rewildingbritain.org.uk/rewilding/rewilding-projects/the-river-wandle, 19.06.2017.

[10] http://www.rewildingbritain.org.uk/rewilding/rewilding-projects/cambrian-wildwood, 19.06.2017.

[11] Mougeot L.J.A. Agropolis. The social, political and environmental dimensions of urban agriculture, International Development Research Centre, Ottawa-Cairo-Dakar-Montevideo-Nairobi-New Delhi-Singapore 2005, XII.

[12] Mougeot L.J.A. Urban agriculture: definition, presence, potential and risks, [w:] Growing cities, growing food: urban agriculture on the policy agenda. A reader on urban agriculture (ed. N. Bakker). German Foundation For International Development, Feldafing 2000, 99-117.

[13] Jégou F., Carey J. Handbook: Creating space for sustainable food systems in urban communities. Practical approaches and examples for cities. Strategic Design Scenarios Publishing, 2016.

[14] http://work.ac/infoodstructure/, 19.06.2017.

[15] Crocket L. Innovative self-sustaining village model could be the future of semi-urban living, [w:] http://www.archdaily.com/794167/innovative-self-sustaining-village-model-could-be-thefuture-of-semi-urban-living, 11.03.2017.

[16] Deelstra T., Girardet H. Urban agriculture and sustainable cities, thematic paper 2 Urban agriculture and sustainable cities, Resource Center on Urban Agriculture and Forestry, Leusden 2008, 48.

[17] Jacobs J. Śmierć i życie wielkich miast Ameryki. Fundacja Centrum Architektury, Instytut Kultury Miejskiej, Warszawa - Gdańsk 2014.

[18] Goodman P. COMMUNITAS means of livelihood and ways of life. Vintage Books, Random House Inc., Nowy Jork 1947, 1960.

\section{Non-urban functions in urban areas as a catalyst for urban life}

\section{Justyna Kleszcz}

Department of Architecture and Urban Planning, Faculty of Civil Engineering, Architecture and Environmental Engineering, University of Zielona Góra, e-mail: j.kleszcz@aiu.uz.zgora.pl

\footnotetext{
Abstract: The paper is intended to approximate the role of multifunctional structures combining typical urban and non-urban functions into one spatial form, which make them nodal points on the local and supra-local scale. These points will be architectural forms of various scales - both those which build space through cubature and create only spatial frames - "anti-cubature". Introduction to cities functions commonly associated with rural areas, such
} 
as agriculture in a variety of forms, animal husbandry, industrial agricultural production, is an inspiration to creating unobvious connections with housing, transportation, office, education, and not only with the area of recreational green in the city. More and more often, buildings of this type become iconic elements of the city structure, both in its physical and virtual space of the "unbuilt" city. Examples of utopian visions created for major metropolises such as New York, Paris, and Vancouver show the importance of small correction of the given space functional program, allowing it to be transformed from lateral into node structure. The Pasona Urban Farm in Tokyo, visions of Vincent Callebaut, WORK Architecture Company or Terreform group, but also the more intimate Amersfoort and Villa Augustus projects in Dordrecht, Hoeve Biesland, show the power dormant in non-urban center - creating functions.

Keywords: city, urban agriculture, urban farming, agropolis, agrihood. 